\title{
Founder effects and geographic variation in the land snail Theba pisana
}

\author{
Michael S. Johnson
}

Department of Zoology, University of Western

The land snail Theba pisana has a history of founder events on Rottnest Island, Western Australia. Compared with populations from the mainland source area, the island populations show a reduction of $\mathbf{3 0}$ to 50 per cent in allozymic variation, depending on the measure used. Similar reductions are associated with secondary founder events on the island itself. The implication is that random sampling has overwhelmed selection in the early history of these populations. From the decay of heterozygosity and the divergence among isolated colonies, the average effective population size over the first 20 to 30 generations of the founder populations was estimated to be about 35 . On a larger scale, the genetic composition of $T$. pisana from Western Australia, Victoria, and Tasmania is consistent with a common source for the Australian introductions. Analysis of samples from southern France, Israel, and Wales supports the hypothesis that $T$. pisana consists of three genetically distinct geographical groupings: Britain, northern France (including some Welsh populations) and the Mediterranean area. Of the populations examined from the native range, only those from southern France have the genetic composition required of the source for the Australian introductions.

\section{INTRODUCTION}

The relative importance of random drift in evolution continues to be one of the major controversies in evolutionary genetics. The most generally accepted case in which stochastic genetic change might be important is in the founding of populations by small numbers of colonists. The severe bottlenecks associated with such founder events should decrease heterozygosity, because of the chance of loss of alleles, and also cause rapid change of allelic frequencies. Such changes at individual loci should be important in changing the genetic environment in which selection operates on interacting genes. The role of such founder effects in speciation has been emphasized by Mayr (1963) and Carson (1968, 1984), and was significant in the development of the theory of punctuated equilibria (Eldredge and Gould, 1972). Founder events may also have effects on the genetics of invading species (e.g., Barrett and Richardson, 1986) and on conservation genetics, as the remnants of endangered species are analogous to founder populations (Carson, 1983; Berry, 1986).

Although the potential effects of founder events are considerable, it is not clear how important they are in real populations (Barton and Charlesworth, 1984). Genetic changes attributed to founder effects can often be explained by localized selection (e.g., Williamson, 1981). species supposedly resulting from founder events often do not have the expected reduction of variation (White, 1978). Even in theory, the impact of founder events on populations is not straightforward. The direct effect on variability may be relatively small, and the important factor is the rate of recovery of population numbers; only if the bottleneck persists will there be substantial reduction of genetic variation (Nei et al., 1975). Determining the genetic impact of founder events is difficult, because it requires a knowledge of the history of founder populations. Introductions of species to new areas by man sometimes provide the opportunity to do this (Barrett and Richardson, 1986).

The land snail Theba pisana is native to coastal regions of the Mediterranean and western Europe, as far north as Ireland and Wales. Founding populations were introduced to Western Australia in the $1890 \mathrm{~s}$, first being noticed near the port of Fremantle. Between 1925 and 1927, a colony was established on Rottnest Island, $15 \mathrm{~km}$ off the mainland coast near Fremantle. Surveys of the distribution of T. pisana on Rottnest were made in 1936, 
1947, 1958, and 1978, providing a documented history of the introduced population (Johnson and Black, 1979). The species has spread in two ways. First, there has been a continuous spread of the colony from the site of introduction at the Settlement area, across much of the eastern portion of the island (fig. 1). In addition, during the Second World War, there were secondary foundations of isolated colonies associated with military encampments in the western portion of the island. The colony at Cape Vlamingh has subsequently spread as far east as Marjorie Bay. A fire in 1974 reduced the extent of the colony, leaving isolated populations at Marjorie Bay and Cape Vlamingh. Although the isolated colonies at Stark Bay and The Bluff were not discovered until 1958 and 1979 respectively, it is likely that they were actually founded during the 1940s, as they also are at sites of military activity. With the exception of the establishment of these secondary colonies, human activities appear to have had little influence on the spread of T. pisana on Rottnest Island (Johnson and Black, 1979). The history of secondary colonization and isolation of the western populations provides a contrast with the spatial and temporal continuity of the eastern populations.

To examine the genetic correlates of this history of founder populations of $T$. pisana, allozymic variation has been studied in mainland and Rottnest Island populations in Western Australia. To consider the genetics of the introduced populations in a broader context, samples from eastern Australia, France, Israel, and Wales have been included in the study. Comparisons among these have been used to answer five questions: (1) how much variation is there in populations of $T$. pisana from its native range? (2) has there been a reduction of variation in the introduced populations in Australia? (3) do the Australian populations have a common source? (4) is it possible, with adequate sampling, to determine the source area or areas? (5) do the allozymes support the hypothesis that T. pisana consists of three genetic and geographical groupings (Cowie, 1984a)?

\section{MATERIALS AND METHODS}

\section{Samples}

Samples were taken from eight sites on Rottnest Island (fig. 1). Four of these are in the eastern portion of the island, where T. pisana has spread from its original colony in the Settlement area. The other four sites are in the western portion of the island, which $T$. pisana has occupied through a series of secondary colonizations. This species was introduced to Rottnest from near Fremantle on the mainland, but the exact locality is unknown. Samples representing the mainland populations were taken from Cottesloe, approximately $4 \mathrm{~km}$ north of Fremantle, and from City Beach, $6 \mathrm{~km}$ further north. Additional Australian samples were obtained from Queenscliff, Victoria, and from Lauderdale, Tasmania.

Populations of $T$. pisana from its native range were represented by two samples from each of three areas. In southern France, samples were obtained from the grounds of the C.N.R.S. in Montpellier and from $16 \mathrm{~km}$ to the east at Valergues. Israel was represented by a sample from

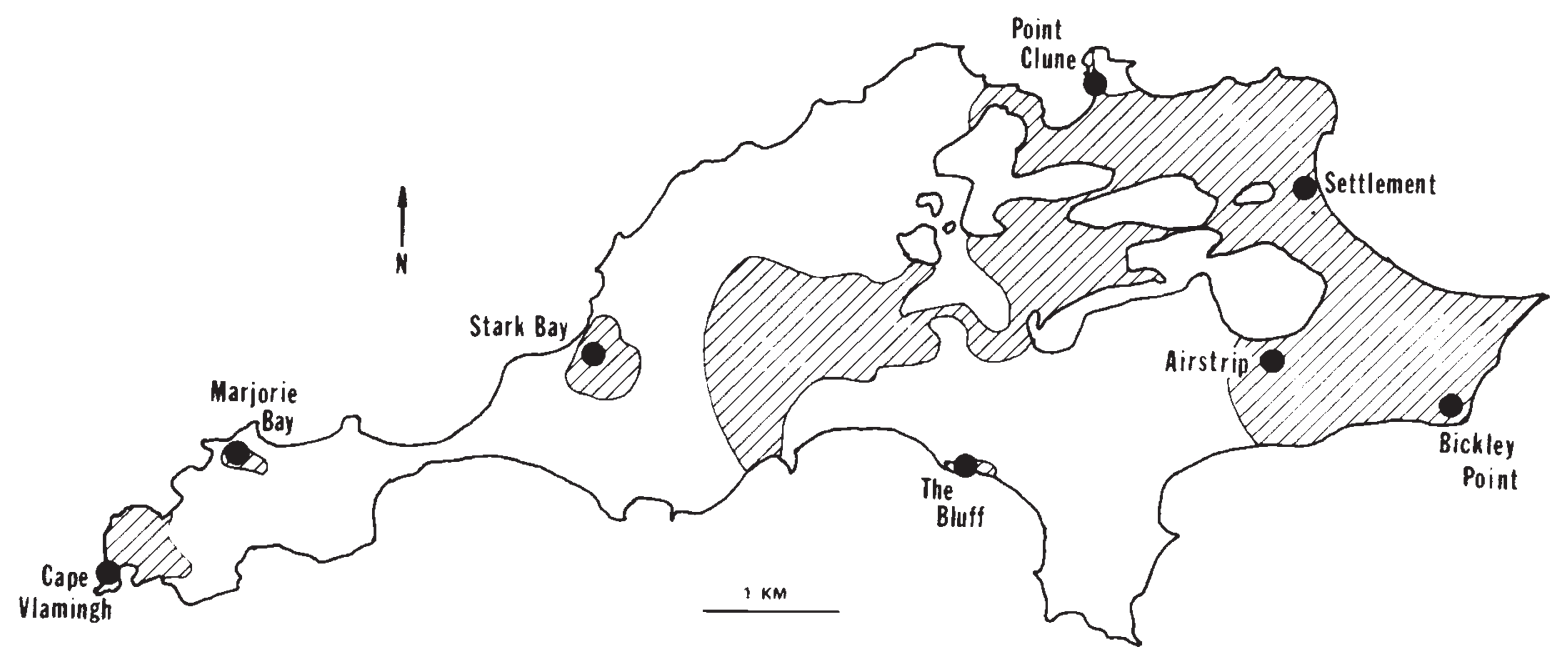

Figure 1 Map of Rottnest Island, showing the distribution (hatched area; from Johnson and Black, 1979) and sample sites of Theba pisana. 
Hofit, $50 \mathrm{~km}$ south of Haifa, and one from Ashdod, $70 \mathrm{~km}$ south of Hofit. Samples from Wales, near the northern limit of the species' range, were obtained from Stackpole Warren in Dyfed, and from Newton, just east of Porthcawl, Glamorgan.

Sample sizes ranged from 20 to 33 , with the exception of the sample of 12 snails from Tasmania. All samples were collected between August, 1984, and November, 1986, and were frozen at $-70^{\circ} \mathrm{C}$ for up to 30 months before electrophoresis.

\section{Electrophoresis}

Samples were examined by conventional horizontal starch-gel electrophoresis. The gels consisted of 8 per cent Sigma hydrolyzed starch and 4 per cent B.D.H. soluble starch. Sixteen enzymes were examined, providing data on 25 gene loci. Abbreviations and electrophoretic conditions are shown in table 1. Although the only other published electrophoretic study of $T$. pisana (Nevo and Bar, 1976) included esterases, $I$. was unable to score the complicated esterase phenotypes consistently, so these enzymes have been excluded from this study. Several of the peptidases are detectable with more than one substrate, one of which has been used for the purpose of labelling the loci (table 1). It is not clear which of these peptidases were included in Nevo and Bar's (1976) study. Phosphoglucomutase was examined using two buffers: PGM-3 was very active with the Tris-maleate buffer, interfering with the scoring of PGM-2; PGM-2 was scored with the Tris-citrate buffer, with which PGM-3 showed poor activity. For all enzymes represented by more than one locus, the loci were labelled numerically, in order of decreasing electrophoretic mobility of the enzymes. Alleles at each locus were labelled according to the mobility of their corresponding allozymes relative to that of the most common allele, which was given a value of 100 . For those loci which are polymorphic in Western Australian populations, Mendelian segregation has been confirmed in comparisons of mothers and offspring (unpublished).

\section{Analyses}

Variability of populations can be characterized in several ways, which may be affected differently by founder events. Consequently, variation within

Table 1 Enzymes assayed and buffer systems used in the study of allozymic variation in Theba pisana

\begin{tabular}{|c|c|c|c|c|}
\hline Enzyme & Locus & Tissue* & $\begin{array}{l}\text { Quaternary } \\
\text { structure } \$\end{array}$ & $\begin{array}{l}\text { Electrophoretic } \\
\text { buffer }{ }^{\dagger}\end{array}$ \\
\hline Glucose-6-phosphate dehydrogenase & G6pd & $\mathrm{F}$ & multimer & $\mathrm{LiOH}$ \\
\hline Glutamate-oxaloacetate transaminase & Got-1 & $\mathrm{H}$ & dimer & TEB \\
\hline$\alpha$-Glycerophosphate dehydrogenase & $\alpha G p d$ & $\mathrm{~F}$ & no data & TEB \\
\hline \multirow{2}{*}{ Isocitrate dehydrogenase } & Idh-1 & $\mathrm{F}$ & dimer & $\mathrm{TM}$ \\
\hline & $I d h-2$ & $\mathrm{~F}$ & no data & $\mathrm{TM}$ \\
\hline Lactate dehydrogenase & $L d h$ & $\mathrm{~F}$ & monomer & TEB \\
\hline Leucine aminopeptidase & Lap-1 & $\mathrm{H}$ & monomer & $\mathrm{TC}$ \\
\hline Leucylglycylglycine peptidase & Lggp-2 & $\mathrm{H}$ & monomer & TEB \\
\hline Leucylproline peptidase & $L p p$ & $\mathrm{~F}$ & no data & $\mathrm{LiOH}$ \\
\hline \multirow[t]{4}{*}{ Leucyltyrosine peptidase } & Ltp-1 & $\mathrm{F}$ & monomer & $\mathrm{LiOH}$ \\
\hline & Ltp-2 & $\mathrm{F}$ & monomer & $\mathrm{LiOH}$ \\
\hline & Ltp-3 & $\mathrm{F}$ & dimer & $\mathrm{LiOH}$ \\
\hline & Ltp-4 & $\mathrm{F}$ & monomer & $\mathrm{LiOH}$ \\
\hline \multirow[t]{3}{*}{ Malate dehydrogenase } & $M d h-1$ & $\mathrm{H}$ & no data & $\mathrm{TC}$ \\
\hline & $M d h-2$ & $\mathrm{H}$ & dimer & $\mathrm{TC}$ \\
\hline & $M d h-3$ & $\mathrm{H}$ & dimer & $\mathrm{TC}$ \\
\hline Malic enzyme & $\mathrm{Me}$ & $\mathrm{F}$ & no data & TM \\
\hline Mannosephosphate isomerase & $M p i$ & $\mathrm{H}$ & no data & TEB \\
\hline 6-Phosphogluconate dehydrogenase & $6 P g d$ & $\mathrm{~F}$ & no data & TEB \\
\hline \multirow[t]{3}{*}{ Phosphoglucomutase } & $P g m-1$ & $\mathrm{~F}$ & monomer & $\mathrm{TM}$ \\
\hline & Pam-2 & $\mathrm{H}$ & nomomer & $\mathrm{TC}$ \\
\hline & Pgm-3 & $F$ & monomer & $\mathrm{TM}$ \\
\hline Phosphoglucose isomerase & $P g i$ & $\mathrm{~F}$ & dimer & TEB \\
\hline \multirow[t]{2}{*}{ Superoxide dismutase } & Sod-1 & $\mathrm{H}$ & dimer & TEB \\
\hline & Sod-2 & $\mathrm{H}$ & no data & TEB \\
\hline
\end{tabular}

\footnotetext{
* $\mathrm{F}=$ foot $\mathrm{H}=$ hepatopancreas.

$\dagger$ Inferred from isozyme patterns of heterozygotes.

$\ddagger \mathrm{TEB}=$ Tris-EDTA-borate $($ buffer 6), $\mathrm{TM}=$ Tris-maleate (buffer 9), $\mathrm{TC}=$ Tris-citrate, (buffer 4), and LiOH= discontinuous lithium hydroxide (buffer 2) of Selander et al. (1971).
} 
populations was expressed in three ways: average expected heterozygosity; average number of alleles per locus; and the per cent polymorphic loci, where a locus was considered polymorphic if the most common allele had a frequency of 0.99 or less.

The genetic similarities between populations were quantified using Nei's (1978) unbiased genetic identity and were summarized by UPGMA clustering (Sneath and Sokal, 1973). For the polymorphic loci, geographic variation among selected groups of populations was quantified using $F_{\mathrm{ST}}$, the standardized variance in allelic frequencies, which was corrected for sampling variance (Wright, 1965). $F_{\mathrm{ST}}$ was determined for each allele, and $F_{\mathrm{ST}}$ for a locus was taken as the weighted average of the allelic values.

Two methods were used to estimate the mean effective size of the Rottnest populations during the period since the colonization. The methods are based on sampling in finite populations, and do not include effects of selection or mutation. The first approach is based on the rate of decay of heterozygosity, which is expressed by

$$
H_{t}=H_{0}[1-(1 / 2 N)]^{t}
$$

where $H_{0}$ is the initial heterozygosity, $H_{t}$ is the heterozygosity after $t$ generations, and $N$ is the harmonic mean of the effective population size over the $t$ generations (Spiess, 1977: 321). Using this relationship, $N$ was estimated separately for the eastern and the western populations on Rottnest Island. $H_{t}$ was taken as the average heterozygosity within the populations of each group. The duration of the life cycle of $T$. pisana is variable (Cowie, 1984b; Baker, 1986), but changes in size-frequency distributions indicate that the species is mainly biennial in these Western Australian populations (unpublished observations). Thus, $t$ is approximately 30 for the eastern populations and 20 for the western populations. For the eastern populations on Rottnest Island, $H_{0}$ was estimated as the average heterozygosity in the two mainland populations. Since the western populations were secondarily derived, $H_{0}$ for them was estimated as the average heterozygosity in the four eastern populations. This estimate is based on the reasonable assumption that heterozygosity in the large, continuous, eastern populations has changed relatively little in the past forty years. If heterozygosities in the source areas have decreased during that period, $N$ will be overestimated. Because it was necessary to use values of $H_{0}$ from the source areas, rather than from the actual founders, the estimates of $N$ include the sampling effects of both the founding event and the postfounding history.

The history of isolation of the western populations on Rottnest Island allows a second approach to the estimation of $N$. The effect of $N$ on the variance in allelic frequencies among isolated populations derived from a common source is given by the formula

$$
F_{\mathrm{ST}}=1-[1-(1 / 2 N)]
$$

(Spiess, 1977, p. 347). In order to estimate $N$, it was assumed that the western populations were derived from a common source 20 generations ago. Since the populations at Cape Vlamingh and Marjorie Bay were separated only in 1974, they were combined as a single population in the calculation of $F_{\mathrm{ST}}$ for the purpose of estimating $N$.

\section{RESULTS}

\section{Western Australian populations}

All of the measures of genetic variation show that the derived populations of Rottnest Island are genetically impoverished compared with the populations in the mainland source area (table 2). Of the 25 loci studied, six are polymorphic in the Western Australian populations. Of these, only four are polymorphic on Rottnest Island. This reduction of polymorphism is due to the absence of the $L t p-1^{96}$ allele, which is relatively uncommon on the mainland, and the $L t p-3^{91}$ allele, which is one of the two equally common alleles on the mainland. The $L t p-2^{105}$ allele, one of three equally common alleles at the Ltp-2 locus on the mainland, is also missing from the Rottnest populations. The average number of alleles per locus is 1.13 in the Rottnest populations, compared with 1.24 in the mainland populations. Since there must be at least one allele per locus, this represents nearly a 50 per cent reduction of "extra" alleles in the Rottnest populations. Similarly, the average heterozygosity over the 25 loci is 30 per cent less in the Rottnest populations than in those on the mainland, 0.048 compared with 0.083 (table 2).

Within Rottnest Island, the secondarily derived western populations are less variable than the eastern populations. Individual populations in the western portion of the island are missing additional common alleles: $I d h-1^{90}$ is missing from Cape Vlamingh and Marjorie Bay; Ltp- $2^{95}$, from Marjorie Bay and Stark Bay; Pgm- $3^{100}$, from Stark Bay; and $P g m-2^{130}$, from The Bluff. The average heterozygosity in the western populations is only 
Table 2 Allelic frequencies and measures of variation in Western Australian populations of Theba pisana. Allelic frequencies are not shown for the 19 loci which were monomorphic in all populations

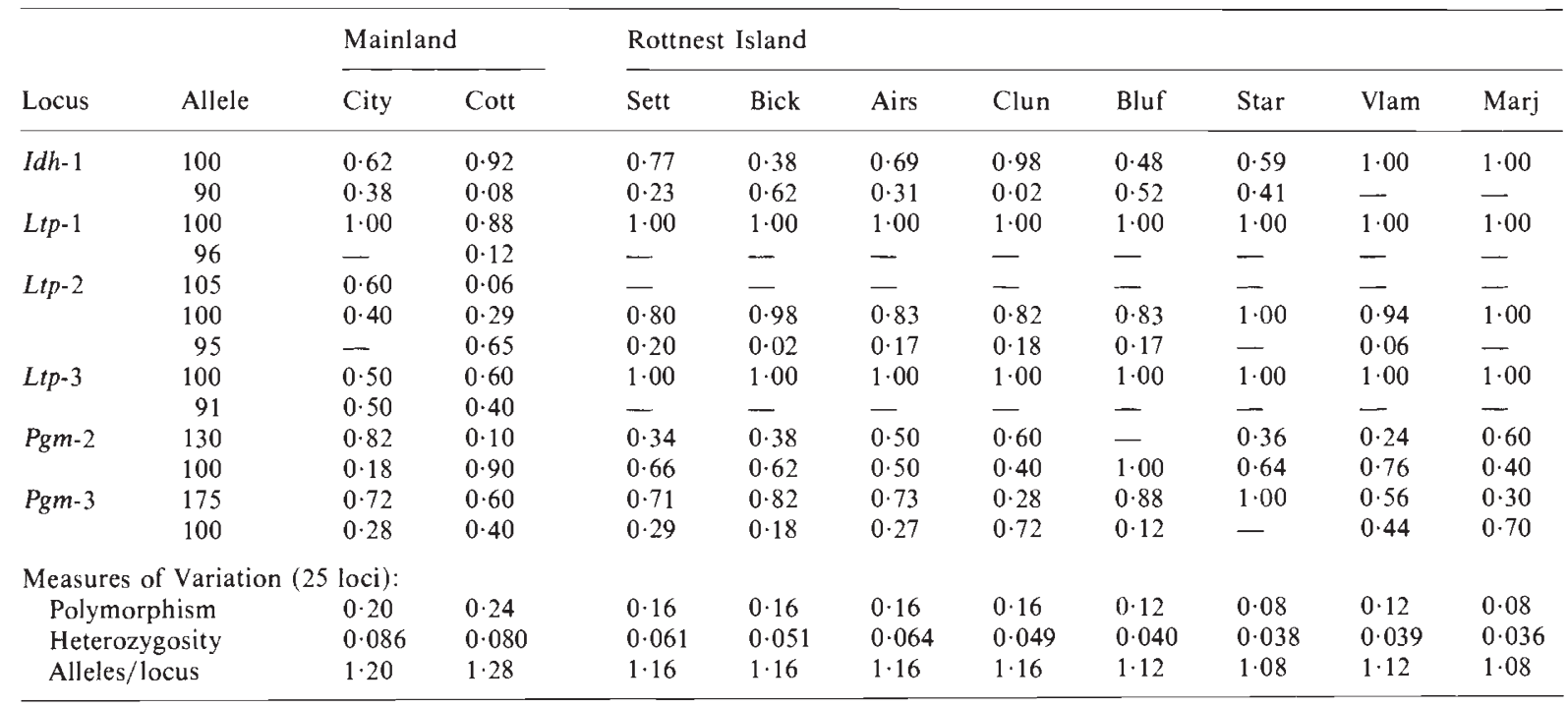

$0 \cdot 038$, compared with 0.056 in the east. Another difference between these sets of populations is that variation among the four isolated western populations, measured by average $F_{\mathrm{ST}}$, is twice as great as that among the connected eastern populations: $0 \cdot 301$ compared with $0 \cdot 140$ (table 3 ).

The estimates of average effective population size during the history of the Rottnest populations are reasonably consistent. The reduction in average heterozygosity in the eastern populations compared with the mainland populations is 32 per cent, which for a period of 30 generations indicates an average effective population size of about 38 . The similar reduction of heterozygosity in the western populations compared with those in the east gives an estimated effective population size of 26 . The divergence among the three western areas (combining Cape Vlamingh and Marjorie Bay, average $\left.F_{\mathrm{ST}}=0 \cdot 210\right)$ gives an estimated effective population size of 41 .

Table 3 Values of $F_{\mathrm{ST}}$ in eastern and western groups of populations of Theba pisana on Rottnest Island

\begin{tabular}{lrr}
\hline Locus & Eastern populations & Western populations \\
\hline Idh-1 & 0.277 & 0.388 \\
Ltp-2 & 0.034 & 0.097 \\
Pgm-2 & 0.019 & 0.276 \\
Pgm-3 & 0.231 & 0.444 \\
Average & 0.140 & 0.301 \\
S.E. & \pm 0.066 & \pm 0.076 \\
\hline
\end{tabular}

\section{Large-scale variation}

Variation was detected at all but eight ( $\alpha G p d, I d h$ 2, Mdh-1, Me, Mpi, Lpp, 6Pgd, and Sod-2) of the 25 loci examined, with populations in the native range being polymorphic for 20 to 44 per cent of the loci (table 4). The two French populations are highly polymorphic, with an average heterozygosity of $0 \cdot 176$. The average value for the Welsh populations is less than half this, at $0 \cdot 066$. The Israeli populations are not consistent: the average hetero ygosity of the Ashdod sample is $0 \cdot 121$, compared with only 0.034 at Hofit. The heterozygosity of the mainland Australian populations is as high as that for Wales and Israel, averaging $0 \cdot 084$. The per cent polymorphism and average number of alleles give a similar picture, except that the Australian populations have the lowest average values for these measures (table 4).

The genetic identities between populations show some clear patterns (fig. 2). The four Mediterranean populations form a cluster at an identity level of 0.96 , within which there is pairing by country. The Australian samples form a group and show a high similarity with those from the Mediterranean, clustering with them at a level of 0.94 . In contrast with these high similarities, the Welsh populations show low similarities with the other populations and with each other, averaging 0.84 to $0 \cdot 87$. The Welsh sample from Newton has highly divergent allelic frequencies at several loci, but does not have unique alleles. The divergence is more striking for the Stackpole population, which 
Table 4 Allelic frequencies and measures of variation in populations of Theba pisana from outside Western Australia. Allelic frequencies are not shown for the eight loci which were monomorphic in all populations. For loci not recorded in table 1, the Western Australian populations are fixed for the " 100 " allele

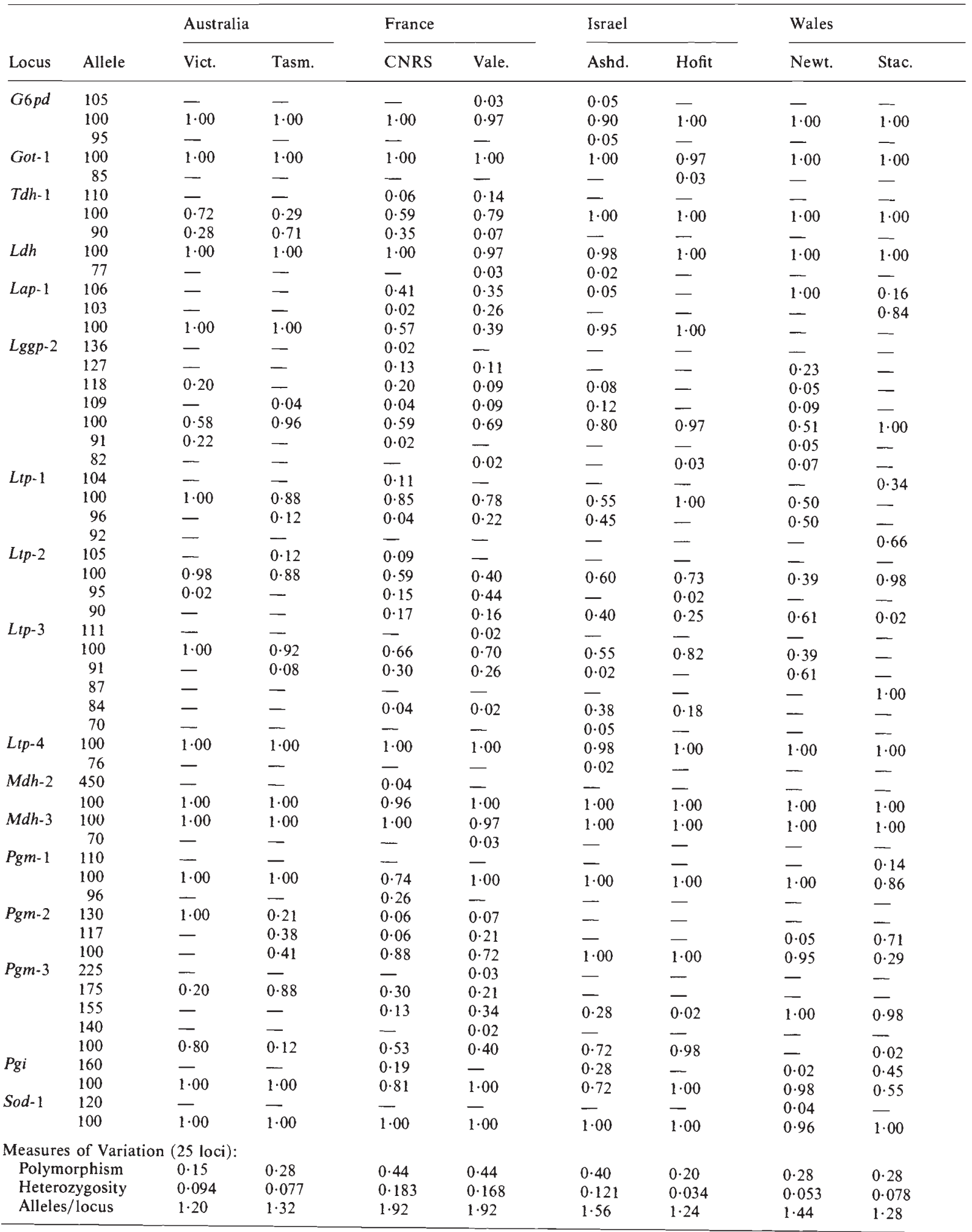




\section{Genetic Identity}

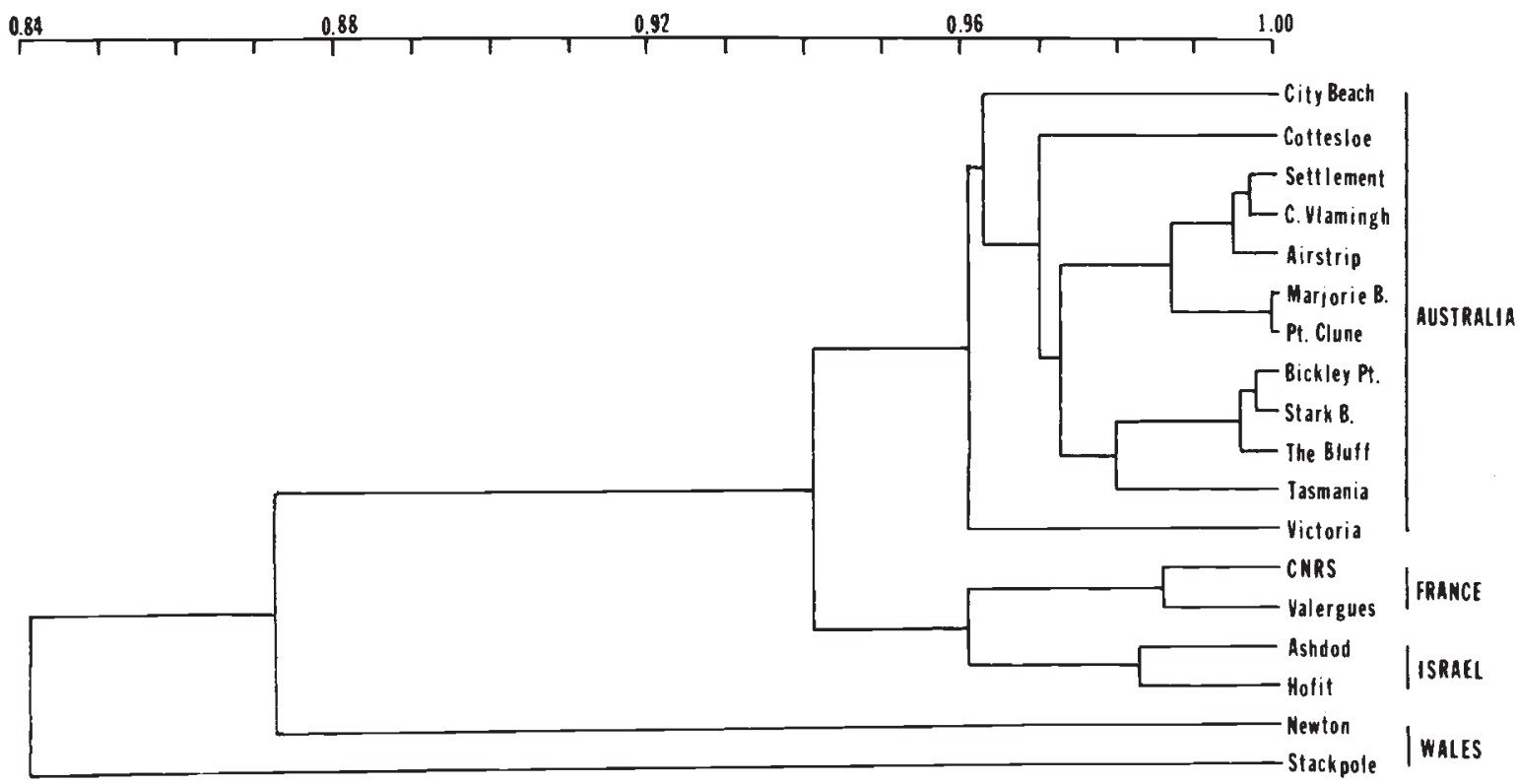

Figure 2 Phenogram (UPGMA clustering) of genetic identities for populations of Theba pisana.

has unique alleles at high frequencies for both Ltp-1 and Ltp-3.

In general, the Australian populations show slightly higher identities with the French populations than with those from Israel. The similarity of the Australian and French populations is more apparent when allelic composition is examined (table 4). All of the alleles detected in Australia are present in the French populations, but several are missing from either Israel or Wales: $I d h-1^{90}$, Ltp-2 ${ }^{105}, P g m-2^{130}$, and Pgm- $3^{175}$ from both Israel and Wales; and Lap-1 ${ }^{100}$ and $L t p-2^{95}$ from Wales.

\section{DISCUSSION}

The history of colonization has left a clear imprint on the genetic makeup of the populations of $T$. pisana on Rottnest Island. The reduced heterozygosity and the loss of the alleles reflect the derivative nature both of the Rottnest colonies compared with mainland populations and of the western compared with the eastern populations on Rottnest. The reduction of heterozygosity in these populations is equivalent to that expected for an effective population size of only about 35 over the period of 20 to 30 generations. By comparison, Cowie (1984c) obtained estimates of effective population sizes of 115 to 4130 in Welsh colonies of $T$. pisana. The relatively small average effective size of the Rottnest populations could reflect very small numbers of founders, slow recovery of population size, or subsequent bottlenecks. As emphasized by Nei et al. (1975), the direct effects of a small number of founders are small. Since each individual in a panmictic population carries, on average, half of the heterozygosity of the population, a single fertilised colonist carries 75 per cent of the heterozygosity of the source population. In the case of $T$. pisana, one pair of snails from the mainland could account for the heterozygosity of the Rottnest colonies. To account for the allelic composition of the Rottnest populations, however, more founders would be required. Using the Cottesloe population from the mainland as an example, the probability that a single pair of snails would have all of the alleles found on Rottnest is only 0.05 ; seven snails would be required to be at least 50 per cent certain of obtaining all of the Rottnest alleles, while 20 snails would be needed for 95 per cent certainty. Since even seven individuals would represent 99 per cent of the heterozygosity in the source population, this suggests that the reduction of heterozygosity occurred at least partly after the founding of the Rottnest populations. Regardless of the actual combination of founder and post-founder effects, the implication of the relatively low allozymic variation is that random sampling has overwhelmed selection in the early history of these populations. 
Since it is often difficult to distinguish between founder effects and selection (e.g., Williamson, 1981 ), it is important to justify this interpretation. The observed patterns are exactly as predicted for the history of bottlenecks: sequential loss of alleles and greater genetic divergence with repeated founder events. Indeed, this predictability is a clear rejoinder to the frequent criticism that evolutionary theory is non-predictive. Despite the considerable divergence among the western populations on Rottnest, the average allelic frequencies are quite similar to those for the eastern group, as would be expected for a set of populations derived independently from a common source. These genetically divergent populations occupy very similar habitats. The main plant species at these sites is Acanthocarpus pressii, which forms a low, dense cover over much of the island. This uniformity, combined with the equalizing effects of the surrounding ocean, makes it highly unlikely that strongly divergent selection is occuring among the Rottnest populations.

The low diversity of the derived populations on Rottnest contrasts with most examples of introduced species, including cane toads (Esteal, 1985) and rabbits (Richardson et al., 1980) in Australia, and, among snails, Cepaea nemoralis in Virginia (Johnson et al., 1984), Cerion casablancae in Florida (Woodruff and Gould, 1987), and Biomphalaria straminea in Hong Kong (Woodruff et al., 1985). In the case of the cane toads, the introduction was large, and the population has continued to grow. Similarly, the introduced population of $C$. casablancae began with 55 individuals and shows no sign of subsequent bottlenecks. For the rabbits, a few dozen individuals very quickly gave rise to large populations. The introduced $B$. straminea has been even more prolific: since its accidental introduction in the early 1970s, it has become locally the most abundant freshwater snail in Hong Kong. Clearly, successful colonists do not typically undergo sufficiently severe bottlenecks to cause a marked reduction of variation; it may well be that the populations that do lose considerable variation are doomed to extinction (Barton and Charlesworth, 1984). In the latter context, it may be worth noting that, despite having been abundant, $T$. pisana has undergone a severe reduction of numbers on Rottnest Island in recent years (Perry, 1978).

While reducing the amount of variation within populations on Rottnest Island, the history of founding events has increased genetic divergence among populations. The combined effects of multiple founder events and isolation are strikingly shown by the two-fold increase in geographic variation among the independent western populations compared with the connected eastern populations. Indeed, the average $F_{\mathrm{ST}}$ of 0.301 among the western populations on Rottnest Island is about three fourths as great as that for the same four loci among the six samples representing the major extent of the native range (average $F_{\mathrm{ST}}=0 \cdot 410$ ). Even the divergence between the Rottnest populations and the mainland is striking. The average genetic distance (Nei, 1978) between Rottnest populations and mainland populations is $0 \cdot 040$. Since this divergence has occurred over a period of 60 years, it represents an increase in genetic distance of 667 per million years, which is nearly 5300 times faster than the average rate estimated for Partula snails in the Society Islands (Johnson et al., 1986) and 11,100 times faster than the rate for vertebrates (Maxson and Maxson, 1979). This means of expressing the divergence emphasizes the large effect that a history of founder populations can have. From an evolutionary perspective, the potential importance is the change in the genetic environment in which future mutation and selection will occur.

There are also practical implications of this result with respect to the use of molecular clocks to infer times of divergence from allozyme data. Based on the commonly used vertebrate "clock" (Maxson and Maxson, 1979), the estimated time of the formation of the Rottnest populations would be more than 600,000 years ago. Over evolutionary time, this effect of bottlenecks on increasing the rate of divergence should be compensated by a decreased rate of change, due to the reduced variation within the derived populations (Chakraborty and Nei, 1977). Nevertheless, the clear implication is that differences in demographic history can make genetic distance a poor indicator of both the onset of divergence and the relationships among populations. For example, the Rottnest populations, on average, are more similar to the Tasmanian population than to those from the source area in Western Australia (fig. 2).

Extension of the analysis of founder effects to the introduction of $T$. pisana to Australia is difficult, because the detailed history is not known. The allelic compositions are consistent with the possibility that colonies in Western Australia, Victoria, and Tasmania had a common source: these areas share the same common alleles, and almost all of the less common ones, at each of the loci examined. With the exception of those in Rottnest Island, the Australian populations have very similar heterozygosities, averaging about 8 per 
cent. Because of the considerable variation in heterozygosity within the native range, however, it is not clear to what extent the variation in the introduced Australian populations has been reduced. The relatively low values for the Welsh populations are probably not typical of the species. These populations are at the extreme of the species' rainge and are probably of fairly recent origin (Cowie, 1984a). The intermediate heterozygosities of the populations from Israel could also reflect a relatively recent occupation of that area. Since $T$. pisana is not present in Pleistocene deposits on the coast of Israel, it probably has arrived in Israel in historic times (Heller and Tchernov, 1978). Although more samples will be required for confirmation, the high heterozygosities of the French populations may be more "typical" for this species in the central part of its range.

In addition to the variation in heterozygosity, there is substantial geographic variation of allelic frequencies in $T$. pisana in its native range. Particularly striking is the genetic divergence of the Welsh populations, botki from those in the Mediterranean region and from each other. This divergence supports Cowie's (1984a) suggestion, based on variation in shell banding, that there are three geographical groupings in T. pisana, two of which are represented in Wales: Britain, northern France (represented by populations near Porthcawl in Wales), and the Mediterranean.

The geographic variation of $T$. pisana provides information about the possible source area of the Australian colonies. Of the three groups in the native range, only the Mediterranean populations could be the source. The Welsh populations are missing several alleles which are common in Australia, and which must have been present in the ancestral populations. Even within the Mediterranean region, it is possible to exclude Israel as the source area, since the Israeli populations also lack alleles which are present in Australia. Nevo and Bar's (1976) study of eight populations, over a distance of $180 \mathrm{~km}$ in Israel, included the Pgm-2 and Pgm-3 loci. The Pgm-2 ${ }^{130}$ allele was not found in any of the populations, and $P g m-3^{175}$ was found in only two, at low frequencies, so that the exclusion of Israel can be made with confidence. In contrast, the French populations possess all of the alleles found in Australia and the most common alleles in the Montpellier area are generally those which are present in Australia. If the Montpellier populations are similar to the ancestral ones, the implication is that approximately 50 per cent of the variation was lost in the colonization of Australia. Since the introductions of $T$. pisana to Australia occurred by sea arourid the turn of the century, however, it is quite possible that the snails came from South Africa, where the species is also introduced. Inclusion of South African populations would be particularly interesting in future studies of possible paths of introduction of this species. While this study provides only an introductory look at geographic variation in $T$. pisana, it shows that more detailed studies are warranted, both in the context of tracing the patterns of introduction and for determining the geographical scale and connectedness of the quite distinct groups within this species.

Acknowledgements I sincerely thank Dr Geoff Baker (C.S.I.R.O. Division of Entomology), Dr Robert Cowie (then of University College, London), Dr J. M. Cullen, (C.S.I.R.O. Biological Control Unit, Montpellier), and Dr Joseph Heller (The Hebrew University of Jerusalem), for provision of the samples which made the large-scale study possible. Dr James Murray made useful comments on the draft. Financial support was provided by the Australian Research Grants Scheme and a CTEC Special Research Grant from the University of Western Australia. Accommodation was provided by the Rottnest Island Biological Research Station.

\section{REFERENCES}

BAKER, G. H. 1986. The biology and control of white snails (Mollusca: Helicidae), introduced pests in Australia. CSIRO Div. Entomol. Tech. Paper No. 25.

BARRETT, S. C. H. AND RICHARDSON, G. J. 1986. Genetic attributes of invading species. In Groves, R. H. and Burdon, J. J. (eds) Ecology of Biological Invasions: An Australian Perspective, Australian Academy of Science, Canberra, pp. 21-33.

BARTON, N. H. AND CHARLESWORTH, B. 1984. Genetic revolutions, founder effects, and speciation. Ann. Rev. Ecol.' Syst., 15, 133-164.

BERRY, R. J. 1986. Genetics of insular populations of mammals, with particular reference to differentiation and founder effects in British small mammals. Biol. J. Linn. Soc., 28, 205-230.

CARSON, H. L. 1968. The population flush and its genetic consequences. In Lewontin, R. C. (ed.) Population Biology and Evolution, Syracuse University Press, New York, pp. $123-137$.

CARSON, H. L. 1983. The genetics of the founder effect. In Schonewald-Cox, C. M., Chambers, S. M., MacBryde, B., and Thomas, W. L. (eds). Benhamin/Cummings, Menlo Park, pp. 189-200.

CARSON, H. L. 1984. Genetic revolutions in relation to speciation phenomena: the founding of new populations. Ann. Rev. Ecol. Syst., 15, 97-131.

CHAKRABORTY, R. AND NEI, M. 1977. Bottleneck effects on average heterozygosity and genetic distance with the stepwise mutation model. Evolution, 31, 347-356.

COWIE, R. H. $1984 a$. Ecogenetics of Theba pisana (Pulmonata: Helicidae) at the northern edge of its range. Malacologia, $25,361-380$. 
COWIE R. H. $1984 b$. The life-cycle and productivity of the land snail Theba pisana (Pulmonata: Helicidae). J. Anim. Ecol., 53, 311-325.

COWIE, R. H. 1984c. Density, dispersal and neighbourhood size in the land snail Theba pisana. Heredity, 52, 381-401.

EI.DREDGE, N. AND GOuLD, S. J. 1972. Punctuated equilibria: An alternative to phyletic gradualism. In Schopf, T. J. M. Models in Paleobiology, Freeman, Cooper, San Francisco, pp. 82-115.

ESTEAL, S. 1985. The ecological genetics of introduced populations of the giant toad Bufo marinus. II, Effective population size. Genetics, 110, 107-122.

HEII.ER, J. AND TCHERNOV, E. 1978. Pleistocene land snails from the coastal plain of Israel. Israel J. Zool., 27, 1-10.

JOHNSON, M. S. AND BLACK, R. 1979. The distribution of Theba pisana on Rottnest Island. West. Australian Natur., 24, 140-144.

JOHNSON, M. S., MURRAY, J. AND CLARKE, B. 1986. An electrophoretic analysis of phylogeny and evolutionary rates in the genus Partula from the Society Islands. Proc. R. Soc. Lond. B, 227, 161-177.

JOHNSON, M. S., STINE, O. C. AND MURRAY, J. 1984. Reproductive compatibility despite large-scale genetic divergence in Cepaea nemoralis. Heredity, 53, 655-665.

MAXSON, I. R. AND MAXSON, R. D. 1979. Comparative albumin and biochemical evolution in plethodontid salamanders. Evolution, 33, 1057-1062.

MAYR, E. 1963. Animal species and Evolution. Belknap Press, Cambridge, Mass

NEI, M. 1978. Estimation of average heterozygosity and genetic distance from a small number of individuals. Genetics, 89 , 583-590.

NEI, M., MARUyAma, T. AND CHAKRABORTY, R. 1975. The bottleneck effect and genetic variability in populations. Evolution, 29, 1-10.
NEVO, E. AND BAR, Z. 1976. Natural selection of genetic polymorphisms along climatic gradients. In Karlin, S. and Nevo, E. (eds) Population Genetics and Ecology, Academic Press, New York, pp. 159-184.

PERRY, D. H. 1978. The mediterranean snail (Theba pisana) on Rottnest Island. West. Australian Natur., 14, 24-25.

RICHARDSON, B. J., ROGERS, P. M. AND HEWITT, G. M. 1980. Ecological genetics of the wild rabbit in Australia. II, Protein variation in British, French and Australian rabbits and the geographical distribution of the variation in Australia. Australian J. Biol. Sci., 33, 371-383.

SEI.ANDER, R. K., SMITH, M. H., YANG, S. Y., JOHNSON, W. E. AND GENTRY, J. B. 1971. Biochemical polymorphism and systematics in the genus Peromyscus. I, Variation in the old-field mouse Peromyscus polinotus. Studies in Genetics VI, University of Texas Publ. 7103, 49-90.

SNEATH, P. H. A. AND SOKAL, R. 1973. Numerical Taxonomy. Freeman, San Francisco.

SPIESS, E. B. 1977. Genes in Populations. John Wiley and Sons, New York.

WHite, M. J. D. 1978. Modes of Speciation. Freeman, San Francisco.

WII.IAMSON, M. 1981. Island Populations. Oxford University Press.

WOODRUFF, D. S. AND GOULD, S. J. 1987. Fifty years of interspecific hybridization: genetics and morphometrics of a controlled experiment on the land snail Cerion in the Florida Keys. Evolution, 41, 1022-1045.

WOODRUFF, D. S., MULVEY, M. AND YIPP, M. W. 1985. Population genetics of Biomphalaria straminea in Hong Kong. $J$. Hered., 76, 355-360.

WRIGHT, S. 1965. The interpretation of population structure by $F$-statistics with special regard to systems of mating. Evolution, 19, 395-420. 